\title{
AMA aims for ethical high road following Sunbeam disaster
}

In an effort to clean house following its debacle with Sunbeam (Delray Beach, FL), the American Medical Association (AMA) announced the departure of three executives key to the ill-fated endorsement deal. A week later it publicized a plan to gather a panel

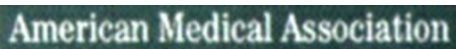

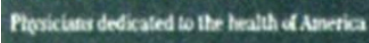

"From 1930 until 1955, the association conducted its 'Seal of Acceptance' program, which required manufacturers not to pay royalties but to advertise in AMA publications. Under the program, various associations appraised medical apparatus and of nationally known medical ethicists to set standards for the group's 300,000 members, as well as its own business deals. In addition, an internal AMA committee is considering the propriety of the organization's business deals.

These events follow the AMA's muchcriticized plan to exclusively endorse Sunbeam's home healthcare products in exchange for a significant fee plus royalties, and the AMA's subsequent repudiation of the endorsement offer due to a firestorm of negative publicity and charges of conflict of interest. The AMA asked Sunbeam to release it from the deal's exclusivity clause, but Sunbeam refused and is now suing the AMA for $\$ 20$ million for breach of contract.

While all reports indicated that this was the first time the AMA had made such an ethical misstep by proposing to endorse products, a former member of the AMA editorial staff, Carl Burkard, disagrees.

evaluated brands of vitamin D milk." It was the threat of a personal injury suit involving products carrying the seal - not fears of conflict of interest - that buried the program, Burkard told Nature Medicine.

The organization has had to postpone plans to publish an alternative medicine book that was approved more than a year ago by two of the three executives who left the organization in the wake of the Sunbeam deal. This follows the cancellation of two lucrative fitness programs, which were to be co-sponsored by the pharmaceutical companies, Hoffmann-La Roche and Procter \& Gamble.

One of the AMA's latest plans is to develop a physicians' accreditation service, which it will offer to managed-care and other organizations for a fee. It is hoped that the new ethics leadership will help the AMA avoid any further embarrassment.

VICKI BROWER New York

\section{Cancer researchers travel to China}

Last week a group of leading US cancer researchers traveled to Beijing to take part in a six day crash course aimed at bringing their Chinese counterparts up to date on the current knowledge of the molecular biology of cancer. The conference was organized by Stephen Friend of the Fred Hutchinson Cancer Center and sponsored by the American Association for Cancer Research (AACR).

Researchers, including Robert Weinberg (Whitehead Institute), Gary Nabel (University of Michigan), Eric Stanbridge (University of California) and Michael Kastan (Johns Hopkins), delivered a series of lectures on fundamental aspects of molecular biology in cancer.

Friend says he was inspired to arrange the meeting after "sifting through stacks of let- ters from Chinese postdocs who want to apply to my lab." Although he appreciated the talent and enthusiasm, he realized that a solid knowledge base in this area was lacking-compounded by the fact that many Western journals do not reach China.

Whether the conference will turn into an annual event "depends on the response from the Chinese scientists," according to the AACR's Jeff Reuben. In fact, as many as 500 Chinese scientists were expected to attend, but a suitably large, non-military venue could not be found, forcing the organizers to settle for the Cancer Institute at the Chinese Academy of Medical Sciences which could house only 150 attendees.

LAURA BONETTA

\section{\$34 million neuropeptide deal}

Neuropeptide research is becoming increasingly valuable, not only in terms of its contribution to medical science but also in terms of hard cash. Warner Lambert recently signed a $\$ 34$ million deal with New Jersey based Synaptic Pharmaceuticals to "advance research on the central actions" of galanin. But is this 29 amino acid gut peptide worth such a significant sum?

Galanin is widely distributed throughout the central nervous system, and has been implicated in a variety of functions, including feeding, cognition and lately as a factor in Alzheimer's disease. To date, two galanin receptor subtypes have been described, but their role in specific functions has yet to be elucidated.

Although neither company will reveal the main therapeutic focus of the agreement, it is tempting to speculate that it is to develop anti-galaninergic compounds for the lucrative and pharmaceutically wide-open area of obesity.

Galanin is known to induce feeding in satiated rats, an effect which can be blocked with peptide antagonists, but the work is still in its infancy and neither Warner-Lambert nor Synaptic is known to possess a therapeutic antagonist candidate.

One factor that may complicate the agreement is Synaptic's pre-existing deal with Novartis to identify compounds that act at NPY receptors. Galanin is co-localized with NPY in a number of brain circuits, and these peptides are believed to have an overlapping role in feeding control. Synaptic insists the two collaborations are completely separate. The companies will be in competition with Bristol-Myers Squibb, which announced a collaboration with the Garvan Institute of Medical Research in Sydney, Australia, last May to study both NPY and galanin in the control of feeding behavior and obesity. However, Bristol-Myer's estimate of galanin's worth is not known since financial terms of this agreement were not disclosed.

Tomas Hökfelt of the Karolinska Institute in Sweden, where galanin was first discovered, told Nature Medicine that he is "delighted to hear that this peptide seems to be worth so much," and that this should dispel doubts as to the usefulness of peptide research. Hökfelt will host a national meeting on galanin in Stockholm next May, and says that he hopes to find out more about the commercial value of galanin from a representative of Synaptic who has been invited. Michelle PAGE 